\title{
Upaya Peningkatan Hasil Belajar Siswa Kelas V Pada Tema 8 Sub Tema 1 Melalui Model Pembelajaran Project Based Learning Di Sekolah Dasar
}

\author{
Budiawan \\ Universitas Sebelas Maret \\ bawan483@gmail.com
}

\section{Article History}

received 3/12/2020

\begin{abstract}
The Aim of this research is to increase the student's study results on theme 8 sub theme 1 in the fifth grade students of SD Negeri Ragatunjung 04, Paguyangan. Brebes in the academic year 2018/2019. This research uses Project Based Learning model and it is an Action Classroom Research. The subject of the study is the students of SD Negeri Ragatunjung 4 for 26 students in the academic year 2018/2019. The Result of the reasearch is find out the precentages of the completeness that students achieves in the first cycle is 11 students (42,30\%) success and 15 $(57,70 \%)$ still get failed, which the average score 68,5 . In the second cycle students succes increase in 24 students $(92,30 \%)$ and 2 students $(7,7 \%)$ still failed because they didn't get average score 84 yet. According to the explanation above can be concluded that using Project Based Learning Model is increasing the students study results on theme 8 sub theme 1 on the fifth grade students of SD Negeri Ragatunjung 4, Paguyangan. Brebes in the academic year 2018/2019.
\end{abstract}

Keywords: project based learning model, results of study

\begin{abstract}
Abstrak
Tujuan penelitian yang akan dicapai adalah untuk meningkatkan hasil belajar siswa pada tema 8 sub tema 1 di kelas V SD Negeri Ragatunjung 04, Kecamatan Paguyangan, Kabupaten Brebes Tahun 2018/2019 melalui model pembelajaran Project Based Learning. Bentuk penelitian ini menggunakan Penelitian Tindakan Kelas. Subjek penelitian yang digunakan adalah siswa kelas V SD Negeri Ragatunjung 04, Kecamatan Paguyangan, Kabupaten Brebes Tahun pelajaran 2018/2019 sebanyak 26 siswa. Hasil penelitian dapat diketahui bahwa presentase ketuntasan belajar siswa pada siklus 1 dari 26 siswa terdapat $11(42,30 \%)$ siswa yang tuntas dan selebihnya $15(57,70 \%)$ siswa belum memperoleh ketuntasan, dengan rata-rata nilai 68,5. Pada siklus 2 dari 26 siswa terdapat $24(92,30 \%)$ siswa yang tuntas dan selebihnya $2(7,7 \%)$ siswa belum memperoleh ketuntasan dengan rata-rata nilai 84 . Berdasarkan keterangan yang ada maka dapat disimpulkan bahwa penggunaan model pembelajaran Project Based Learning dapat meningkatkan hasil belajar siswa pada tema 8 sub tema 1 di kelas V SD Negeri Ragatunjung 04, Kecamatan Paguyangan, Kabupaten Brebes Tahun pelajaran 2018/2019.
\end{abstract}

Kata kunci: model project based learning, hasil belajar

Social, Humanities, and Education Studies (SHEs): Conference Series https://jurnal.uns.ac.id/shes 


\section{PENDAHULUAN}

Proses belajar mengajar diharapkan dapat memberikan pengalaman kepada peserta didik sebagai subjek dalam belajar. Selain itu, pembelajaran diharapkan dapat memberikan bekal bagi peserta didik untuk hidup di masyarakat baik sikap, pengetahuan, dan keterampilan. Upaya untuk memperoleh pengalaman diperlukan adanya interaksi yang efektif baik antar guru dengan peserta didik, antara peserta didik dengan peserta didik, maupun antara peserta didik dengan lingkungan belajarnya untuk dapat mencapai tujuan pembelajaran. Guru berperan sebagai fasilitator yang bertugas untuk mendorong peserta didik aktif dalam upaya memperoleh pengalaman. Pembelajaran tidak hanya sebatas transfer of knowledge tetapi juga membutuhkan proses aktif peserta didik untuk membangun sendiri pengetahuanya.

Pembelajaran (Zainal Arifin, 2012:3). Merupakan suatu sistem, maksudnya pembelajaran merupakan satu komponen yang satu sama lain saling berkaitan dan saling berinteraksi untuk mencapai suatu hasil yang optimal sesuai tujuan yang telah ditentukan. Pembelajaran sebagai suatu sistem memiliki berbagai komponen, antara lain: tujuan, materi, metode, media, sumber belajar, evaluasi, peserta didik, lingkungan dan guru yang saling berhubungan dan ketergantungan satu sama lain serta berlangsung terencana. Pembelajaran dapat dikatakan efektif apabila setiap komponen pembelajaran dapat melaksanakan peranya secara maksimal.

Proses pembelajaran harus menciptakan aktivitas pembelajaran baik dilakukan oleh guru maupun peserta didik. Aktivitas peserta didik dalam proses pembelajaran dapat merangsang dan mengembangkan bakat yang dimilikinya, peserta didik cenderung berpikir kritis, dan dapat memecahkan masalah dalam pembelajaran. Aktivitas belajar adalah dasar untuk guru (pendidik) dan siswa (peserta didik) untuk mencapai tujuan dan hasil belajar. Dengan adanya aktivitas maka proses pembelajaran dapat berlangsung dengan baik. Aktivitas dalam proses pembelajaran berpusat kepada siswa sebagai peserta didik.

Hasil observasi awal dalam pembelajaran Tema 8 Subtema 1 kelas V SD Negeri Ragatunjung 04, Kecamatan Paguyangan, Kabupaten Brebes Tahun pelajaran 2018/2019 menunjukkan proses pembelajaran tidak berlangsung sebagaimana mestinya. Kegiatan pembelajaran hanya melibatkan peserta didik tertentu yang aktif sedangkan peserta didikyang lain kurang memperhatikan pelajaran. Ketika guru mengajukan pertanyaan, empat orang peserta didik tidak dapat menjawab pertanyaan yang diberikan. Selain itu, seperempat dari jumlah peserta didik di kelas lebih memilih berbicaradengan temannya dan bermain-main dari pada mendengarkan penjelasan guru.

Kurangnya inovasi dalam pembelajaran menjadikan beberapa peserta didik terlihat bosan, hal tersebut terlihat ketika guru memberikan kesempatan bertanya tetapi tidak ada satupun peserta didik yang bertanya. Hal tersebut menunjukkan rasa keingin tahuan peserta didik yang masih rendah.

Menanggapi masalah tersebut di atas, model pembelajaran yang lain perlu diterapkan yaitu model pembelajaran yang lebih berpusat kepada siswa. Banyak model pembelajaran yang bisa digunakan, salah satunya adalah model pembelajaran berbasis proyek (Project Based Learning). Model pembelajaran ini merupakan pembelajaran kreatif yang berpijak pada identifikasi dan analisis atau masalah yang ada di lingkungan sekolah. Model pembelajaran project based learning ini dirasa mampu diterapkan untuk mengatasi permasalahan-permasalahan pada kegiatan pembelajaran karena siswa dituntut untuk lebih kreatif dalam pembuatan produk.

Berdasarkan latar belakang di atas, dapat dirumuskan masalah sebagai berikut :

1. Apakah melalui model Project Based Learning dapat meningkatkan hasil belajar siswa kelas $\mathrm{V}$ pada pembelajaran Tema 8 Subtema 1 semester 2 SD Negeri Ragatunjung 04 Tahun Pelajaran 2018/2019?

2. Bagaimana meningkatkan hasil belajar siswa melalui model Project Based Learning 
di kelas V SD Negeri Ragatunjung 04?

Dari uraian latar belakang dan rumusan masalah di atas Penelitian Tindakan Kelas ini secara umum memiliki tujuan untuk mengatasi masalah yang terjadi pada pembelajaran supaya pembelajaran yang berlangsung mendapatkan hasil yang lebih baik sehingga prestasi belajar siswa meningkat. Sedangkan secara khusus tujuan dari penelitian ini adalah sebagai berikut:

1. Untuk mengetahui apakah model project based learning dapat meningkatkan hasil belajar peserta didik kelas $V$ pada pembelajaran Tema 8 subtema I semester 1 SD Negeri Ragatunjung 04 Tahun Pelajaran 2018/2019.

2. Untuk mengetahui bagaimanakah model project based learning dapat meningkatkan hasil belajar peserta didik kelas $V$ pada pembelajaran Tema 8 Sub Tema 1 SD Negeri Ragatunjung 04 Tahun Pelajaran 2018/2019.

\section{METODE}

Sekenario penelitian berisi garis besar pelaksanaan Penelitian Tindakan Kelas yang dilakukan. Penelitian Tindakan Kelas dilaksanakan dalam dua siklus yaitu siklus I dan siklus II. Setiap siklus terdiri dari satu kali pertemuan. Bila dirasa sangat perlu dapat dipertimbangkan untuk dilakukan siklus selanjutnya.

Penelitian menggunakan strategi Spiral Kemmis dan MC Tanggart (dalam Kasbuloh 1998:114) secara berulang-ulang, semakin lama, diharapkan semakin meningkatkan perubahanya atau pencapaian hasilnya. Dalam perencanaan Kemmis menggunakan sistem spiral yang dimulai dengan rencana, tindakan, pengamatan, refleksi, perencanaan kembali merupakan dasar untuk suatu ancang-ancang pemecahan masalah.

Penelitian ini mengambil lokasi di SD Negeri Ragatunjung 04 yang beralamatkan di dukuh Krajan Rt 05 Rw 05 Desa Ragatunjung, Kecamatan Paguyangan, Kabupaten Brebes. Waktu pelaksanaan Penelitian Tindakan Kelas di kelas $\mathrm{V}$ dengan jumlah siswa sebanyak 26 pada tahun pelajaran 2018/2019 pelaksanaan menyesuaikan dengan jadwal pembelajaran semester genap pada tema 8 subtema 1.

\section{HASIL DAN PEMBAHASAN}

Berdasarkan observasi awal sebelum penelitian diketahui bahwa pada kelas V SD Negeri Ragatunjung 04 memiliki beberapa permasalahan yang dialami siswa selama proses pembelajaran. Permasalahan tersebut antara lain: 1) kurangnyaaktivitas belajar siswa selama proses pembelajaran, 2) antusiasme siswa terhadap proses pembelajaran masih rendah, dan 3) pemahaman siswa terhadap materi yang disampaikan masih rendah. Pemahaman yang rendah ini dapat dilihat dari hasil nilai Ulangan Harian 1 pada semester 2 tahun pelajaran 2018/2019 pada tabel berikut:

Tabel 1. Nilai Ulangan Harian 1 pada semseter 2 tahun pelajaran 2018/2019

\begin{tabular}{lcc}
\hline \multicolumn{1}{c}{ Hasil Belajar UH 1 } & Teori & Nilai \\
\hline Nilai Tertinggi & 95 & Praktik \\
Nilai Terendah & 55 & 100 \\
Rata-rata & 72 & 85 \\
Jumlah Siswa Tuntas & 10 & 90 \\
Jumlah Siswa yang Mengikuti Ulangan & 26 & 24 \\
Presentase Ketuntasan (\%) & 45 & 30 \\
\hline
\end{tabular}

Berdasarkan tabel di atas dapat dijelaskan bahwa hasil belajar siswa belum mencapai nilai KKM yang ditetapkan yaitu 75 . Setelah diketahui kurangnya aktivitas belajar siswa yang masih rendah, perlu dilakukan tindakan agar hal tersebut dapat 
meningkatkan hasil belajar peserta didik. Maka guru akan mengimplementasikan model pembelajaran project based learning. Sebelum diberi tindakan guru menetapkan kompetensi dasar yang digunakan sebagai materi pada pengimpelemntasian model pembelajaran project based learning. Kemudian disusun rancangan pembelajaran berupa Rencana Pelaksanaan Pembelajaran (RPP) berdasrakan kurikulum 2013. Pembuatan RPP dilakukan secara mandiri dan ditentukan KKM yaitu 75.

\section{Siklus I}

Pada siklus I pelaksanaan tindakan meliputi motivasi belajar, hasil belajar peserta didik dan kinerja guru. Sikap belajar peserta didik dideskripsikan untuk mengetahui minat belajar peserta didik. Dan pada hasil belajar peserta didik dapat di lihat perolehan nilai ketuntasan belajar peserta didik. Sedangkan kinerja guru dideskripsikan dalam kemampuan guru menggunakan metode project based learning dalam pembelajaran daring Tema 8 Subtema 1. Pelaksanaan evaluasi pembelajaran siklus I setelah menggunakan model pembelajaran project based learning, menunjukkan hasil evaluasi nilai rata-rata kelas dan pesentase ketuntasan belajar dapat di lihat dari tabel berikut :

Tabel 2. Hasil Belajar Siklus I

\begin{tabular}{ccc}
\hline No & Keterangan & Siklus 1 \\
\hline $\mathbf{1}$ & Jumlah Nilai & 1780 \\
$\mathbf{2}$ & Rata-rata Nilai & 68,5 \\
$\mathbf{3}$ & Jumlah Tuntas & 11 siswa \\
$\mathbf{4}$ & Jumlah Belum Tuntas & $15 \mathrm{siswa}$ \\
$\mathbf{5}$ & Presentase Tidak Tuntas & $57,7 \%$ \\
$\mathbf{6}$ & Presentase Tuntas & $42,30 \%$ \\
\hline
\end{tabular}

Berdasarkan tabel di atas dapat diketahui bahwa pada pembelajaran siklusI nilai rata-rata kelas mencapai 68,5. Pencapaian tersebut telah memenuhi kriteriaketuntasan minimal (KKM) Tema 8 Subtema 1 yaitu sebesar 75. Jika dalam nilai tersebut peserta didik kurang dari 75 maka dikatakan peserta didik tersebut belumtuntas. Pencapaian hasil belajar peserta didik dapat di lihat pada diagram berikut ini:

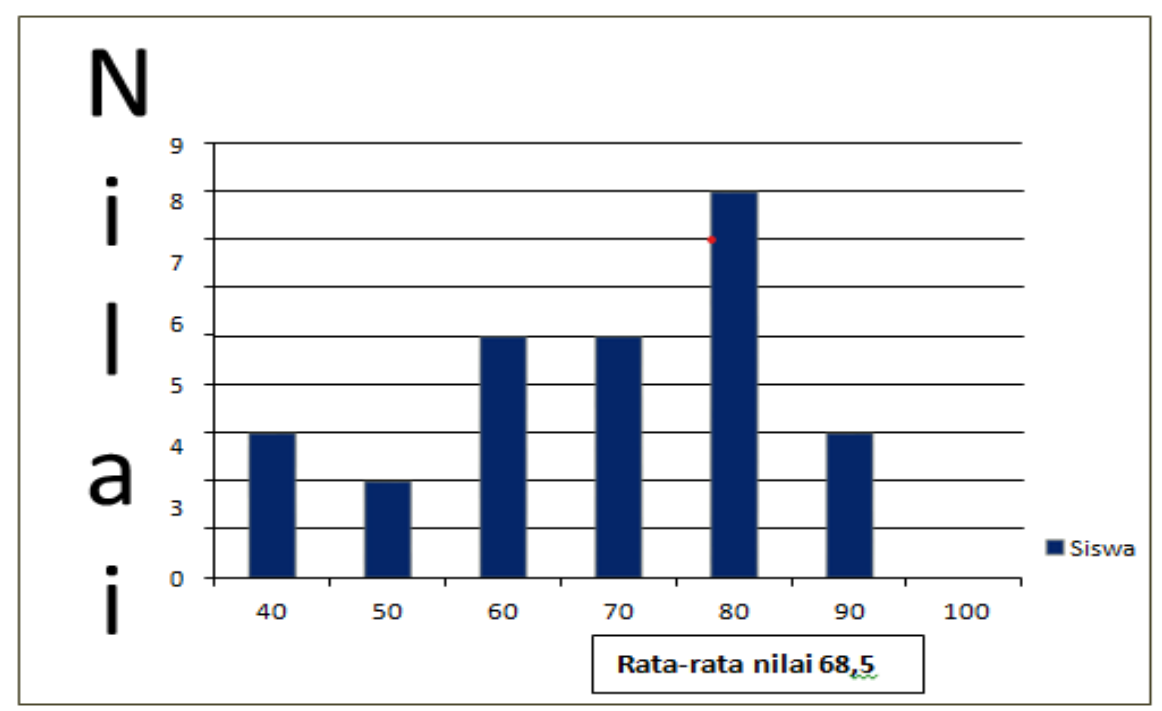

Gambar 1. Perolehan Nilai Siklus I 


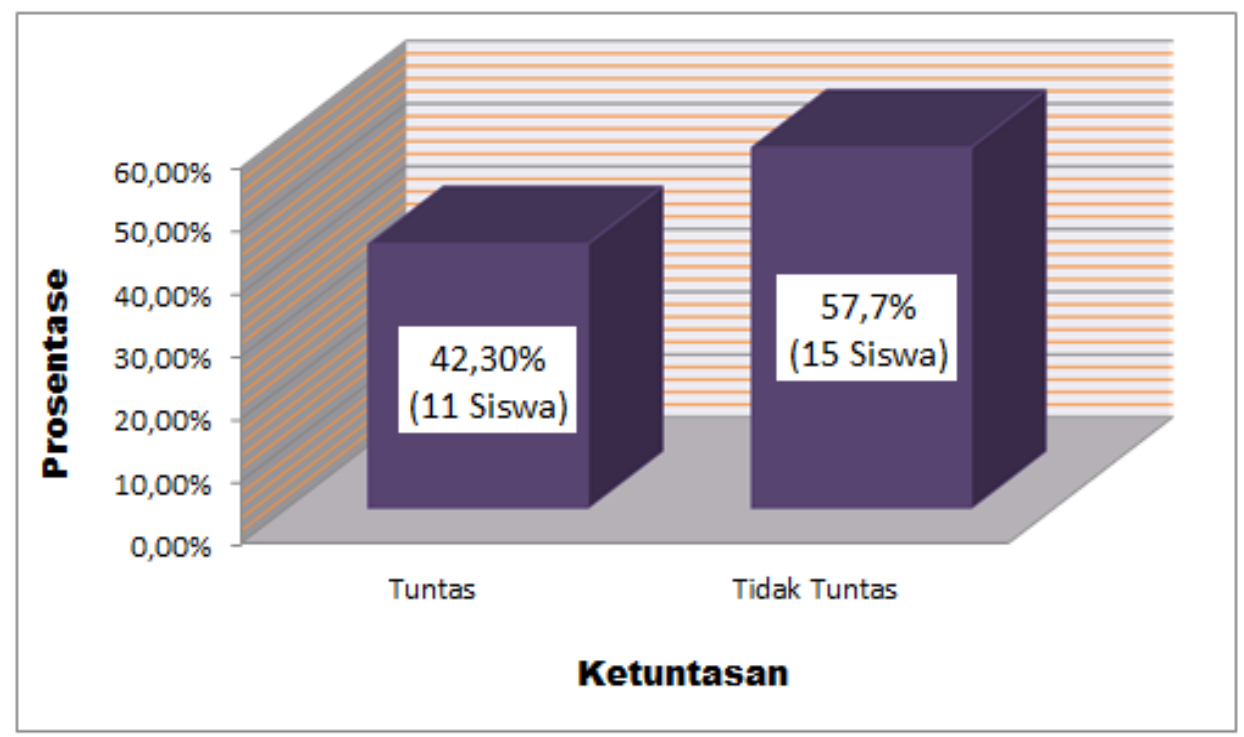

Gambar 2. Diagram Ketuntasan Hasil Belajar Siklus I

Berdasarkan Indikator pencapaian yang ingin dicapai penulis bahwa pembelajaran dikatakan berhasil jika $80 \%$ atau lebih dari seluruh peserta didikmencapai ketuntasan dengan KKM 75 dan Rata-rata hasil belajar klasikal mencapai 75. Dengan demikian hasil pada siklus 1 tidak terpenuhi maka Kegiatanpembelajaran akan diperbaiki dengan siklus II.

\section{Siklus II}

Pada siklus II pelaksanaan tindakan meliputi sikap belajar dan hasil belajar peserta didik. Sikap belajar peserta didik dideskripsikan untuk mengetahui sikap sosial peserta didik. Dan pada hasil belajar peserta didik dapat di lihat perolehan nilai ketuntasan belajar peserta didik. Sedangkan kinerja guru dideskripsikan dalam kemampuan guru mengajar dalam pembelajaran Tema 8 Subtema 1.

Pelaksanaan evaluasi pembelajaran siklus II setelah kegiatan pembelajaran mengggunakan model project based learning, menunjukkan hasil evaluasi nilai rata-rata kelas dan pesentase ketuntasan belajar dapat di lihat dari tabel berikut:

Tabel 3. Hasil Belajar Siklus II

\begin{tabular}{ccc}
\hline No & Keterangan & Siklus II \\
\hline $\mathbf{1}$ & Jumlah Nilai & 2185 \\
$\mathbf{2}$ & Rata-rata Nilai & 84 \\
$\mathbf{3}$ & Jumlah Tuntas & 14 siswa \\
$\mathbf{4}$ & Jumlah Belum Tuntas & 2 siswa \\
$\mathbf{5}$ & Presentase Tidak Tuntas & $7,7 \%$ \\
$\mathbf{6}$ & Presentase Tuntas & $92,30 \%$ \\
\hline
\end{tabular}

Berdasarkan tabel di atas dapat diketahui bahwa pada pembelajaran siklus 2 nilai rata-rata kelas mencapai 84 . Pencapaian tersebut telah memenuhi kriteria ketuntasan minimal (KKM) yaitu sebesar 75 . Jika dalam nilai tersebut peserta didik kurang dari 75 maka dikatakan peserta didik tersebut belum tuntas. Prestasi belajar peserta didik kelas 5SD Negeri Ragatunjung 04 pada pembelajaran Tema 8 Sub Tema 1 , dari 26 peserta didik hanya ada $24(92,30 \%)$ peserta didik yang tuntas (nilai $\geq \mathrm{KKM}$ ) dan selebihnya 2 peserta didik $(7,7 \%)$ belum memperoleh ketuntasan (nilai $\leq K K M$ ) dengan rata-rata nilai 
hasil belajar 84 .

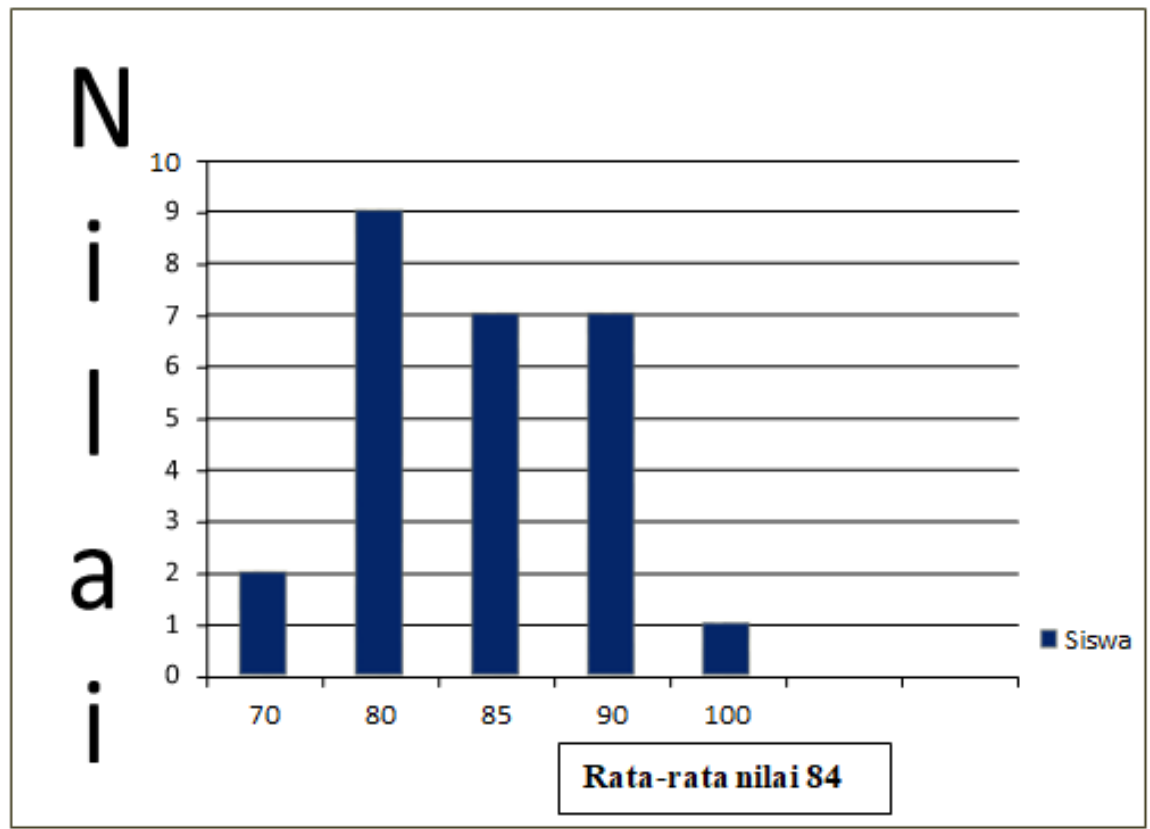

Gambar 3. Grafik Perolehan Nilai Siklus II

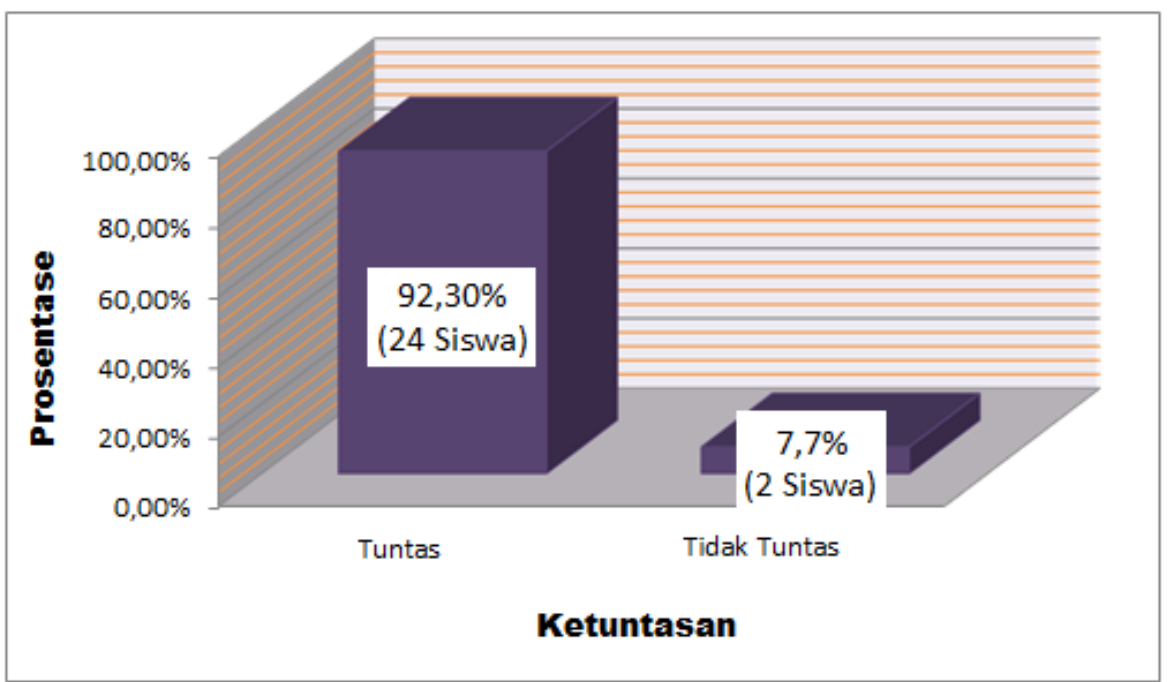

Gambar 4. Diagram Ketuntasan Hasil Belajar Siklus II

Hasil tersebut dikatakan mengalami peningkatan yang cukup berhasil karena telah memenuhi KKM yang telah ditetapkan yaitu sebesar 75 . Sudah ada 24peserta didik yang mencapai ketuntasan dan ada 2 peserta didik yang belummengalami ketuntasan.

\section{Pembahasan Antar Siklus}

Dalam Proses belajar mengajar harus dapat menciptakam kondisi yang dapat melibatkan peserta didik secara aktif. Mengaktifkan peserta didik selama proses belajar mengajar tersebut dengan mengaitkan pembelajaran dengan kehidupan nyata, sehingga ada perubahan dalam kegiatan yang berpusat pada guru menjadi berpusat pada peserta didik dan menjadikan pembelajaran yang bermakna karena peserta didik ikut terlibat dalam proses pembelajaran. 
Model Project Based Learning merupakan proses pembelajaran yangmenciptakan aktivitas peserta didik untuk membuat produk. Para peserta didik didorong untuk berkolaborasi membuat karya, serta berpikir dengan cara analitik, kritis dan kreatif agar bisa mendapatkan solusi dari permasalahan yang diberikan secara mandiri.Tugas guru dalam lingkungan belajar berbasis pertanyaan ini bukanlah untuk menyediakan pengetahuan, namun membantu peserta didik menjalani proses menemukan sendiri pengetahuan yang mereka cari. Guru berfungsi sebagai fasilitator dan bukan sumber jawaban.

Berdasarkan analisis yang dilakukan pada data penelitian ini menunjukan bahwa model project Based Leraning memiliki dampak positif dalam meningkatkan hasil belajar peserta didik pada tema 8 sub tema 1 antara lain:

1. Peningkatan hasil belajar pada siklus I dari 26 peserta didik terdapat $11(42,30 \%)$ peserta didik yang tuntas (nilai $\geq \mathrm{KKM}$ ) dan selebihnya 15 peserta didik $(57,70 \%)$ belum memperoleh ketuntasan (nilai $\leq \mathrm{KKM}$ ) dengan rata-rata nilai hasil belajar 68,5.

2. Peningkatan hasil belajar pada siklus II dari 26 peserta didik terdapat 24 peserta didik $(92,30 \%)$ peserta didik yang tuntas (nilai $\geq \mathrm{KKM}$ ) dan selebihnya 2 peserta didik $(7,7 \%)$ belum memperoleh ketuntasan (nilai $\leq \mathrm{KKM}$ ) dengan rata-rata nilaihasil belajar 84

Untuk dapat melihat rekapitulasi hasil belajar dan ketuntasan per siklus dapat dilihat dari tabel dan grafik berikut :

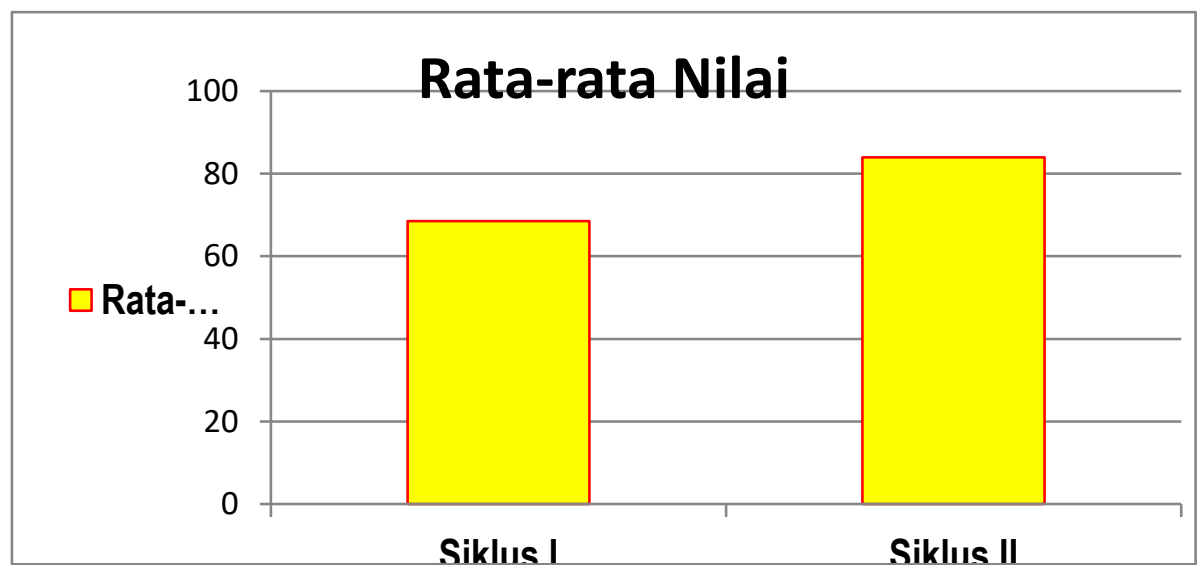

Gambar 5. Grafik Rekapitulasi Perolehan Nilai Tema 8 Sub Tema 1 Per Siklus

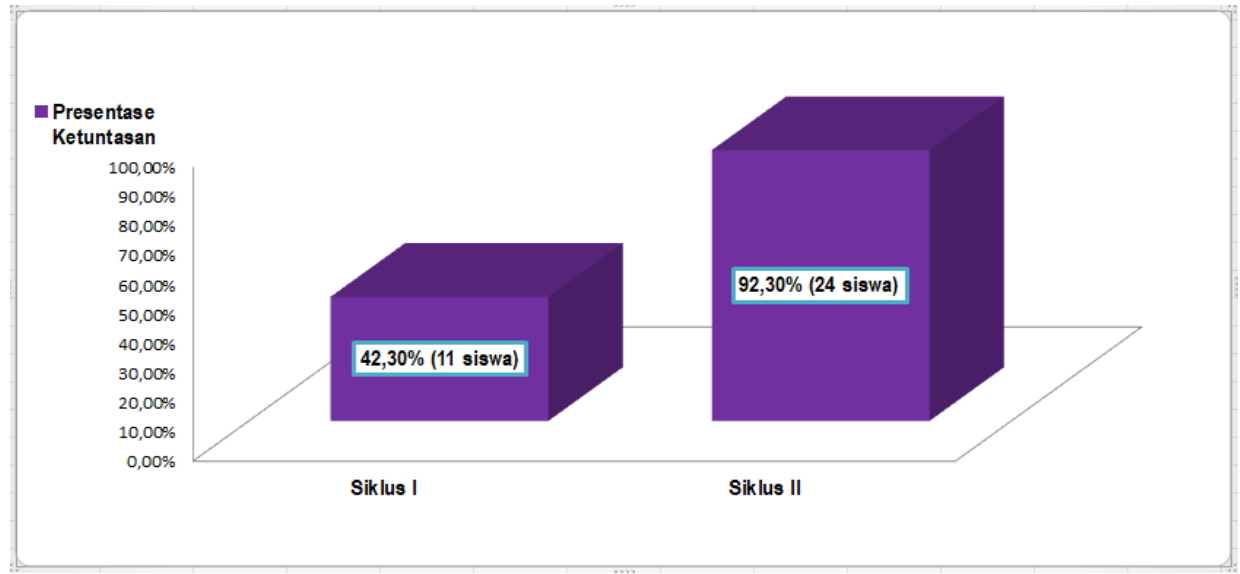

Gambar 6. Diagram Presentase Ketuntasan Nilai Tema 8 Sub Tema 1 Per Siklus

SIMPULAN 
Kesimpulan berdasarkan hasil penelitian dan pembahasan tentang peningkatan hasil belajar peserta didik pada tema 8 sub tema 1 model pembelajaran Project Based Learning pada peserta didik kelas V SD Negeri Ragatunjung 04 adalah sebagai berikut: 1. Penerapan model pembelajaran Project Based Learning telah berjalan dengan baik, dan mampu meningkatkan hasil belajar peserta didik kelas $V$ pada tema 8 sub tema 1. Hal ini dibuktikan dengan meningkatnya hasil belajar peserta didik pada siklus I sebesar 42,30 \% dan siklus II sebesar 92,30\%.

2. Pada pembelajaran ini, peserta didik dituntut untuk melakukan, menyimpulkan dan membuat hipotesis sendiri terhadap materi yang telah disampaikan sehingga membutuhkan perhatian dan pemahaman sehingga memenuhi tujuan pembelajaran.

Saran berdasarkan hasil penelitian yang dilaksanakan menggunakan model pembelajaran Project Based Learning adalah sebainya guru selektif dalam memilih model pembelajaran yang akan dilaksanakan, model tersebut harus disesuaikan dengan materi pembelajaran yang akan disampaikan kepada peserta didik dan bagi pihak pemerintah ataupun sekolah agar secara konsisten memberikan fasilitas bagi pengembangan profesionalisme guru.

\section{DAFTAR PUSTAKA}

Eko Mulyadi. (2015). Penerapan Model Project Based Learning untuk meningkatkan Kinerja dan Prestasi Belajar Fisika Siswa SMK. Jurnal Pendidikan Teknologi dan Kejuruan. Yogyakarta UNY.

Made Wena. (2009). Strategi Pembelajaran Inovatif Kontemporer. Jakarta: PT Bumi Aksara.

Martinis Yamin. (2013). Desain Pembelajaran Berbasis Tingkat Satuan Pendidikan. Jakarta:Referensi.

Muhammad Fathurrohman. (2015). Model-model Pembelajaran Inovatif. Yogyakarta: ArRuzz Media.

Mulyasa. (2014). Pengembangan Implementasi Kurikulum 2013. Bandung: PT Remaja Rosdakarya Offset.

Nana Sudjana. (2014). Penilaian Hasil Proses Belajar Mengajar. Bandung: PT Remaja Rosdakarya.

Sardiman A.M (2014). Interasi dan Motivasi Belajar Mengajar. Jakarta: Rajawali Press.

Siregar, Eveline dan Hartini Nara. (2011). Teori Belajar dan Pembelajaran. Bogor: Ghalia Indonesia.

Sugihartono, dkk. (2012). Psikologi Pendidikan. Yogyakarta: UNY Press.

Sugiyono. (2013). Metode Penelitian Pendidikan. Bandung: ALFABETA.

Warsono dan Hariyanto. (2013). Pembelajaran Aktif. Bandung: PT Remaja Rosdakarya. Wijaya Kusumah \& Dedi Dwitagama. (2010). Mengenal Penelitian Tindakan Kelas. Jakarta: PT. Indeks.

Zainal Arifin. (2013). Evaluasi Pembelajaran. Bandung: PT Remaja Rosdakarya. 